BACKGROUND: We have previously shown that the calcium-binding protein MRP-14 secreted by neutrophils mediates the antinociceptive response in an acute inflammatory model induced by the intraperitoneal injection of glycogen in mice.

Aim: In an attempt to broaden the concept that neutrophils and MRP-14 controls inflammatory pain induced by different type of irritants, in the present study, after demonstrating that carrageenan (Cg) also induces atinociception in mice, we investigated the participation of both neutrophils and MRP-14 in the phenomenon.

Methods: Male Swiss mice were injected intraperitoneally with $\mathrm{Cg}$ and after different time intervals, the pattern of cell migration of the peritoneal exudate and the nociceptive response of animals submitted to the writhing test were evaluated. The participation of neutrophils and of the MRP-14 on the $\mathrm{Cg}$ effect was evaluated by systemic inoculation of monoclonal antibodies anti-granulocyte and anti-MRP-14.

Results: Our results demonstrate that the acute neutrophilic peritonitis evoked by $\mathrm{Cg}$ induced antinociception 2,4 and $8 \mathrm{~h}$ after inoculation of the irritant. Monoclonal antibodies anti-granulocyte or anti-MRP-14 reverts the antinociceptive response only 2 and $8 \mathrm{~h}$ after $\mathrm{Cg}$ injection. The antibody antiMRP-14 partially reverts the antinociception observed after $4 \mathrm{~h}$ of $\mathrm{Cg}$ injection while the anti-granulocyte antibody enhances this effect. This effect is reverted by simultaneous treatment of the animals with both antibodies. After $4 \mathrm{~h}$ of $\mathrm{Cg}$ injection in neutrophildepleted mice a significant expression of the calciumbinding protein MRP-14 was detected in the cytoplasm of peritoneal macrophages. This suggests that the enhancement of the effect observed after treatment with the anti-neutrophil antibody may be due to secretion of MRP-14 by macrophages. It has also been demonstrated that endogenous opioids and glucocorticoids are not involved in the antinociception observed at the 4th hour after $\mathrm{Cg}$ injection.

Conclusion: These data support the hypothesis that neutrophils and the calcium-binding protein MRP-14 are participants of the endogenous control of inflammatory pain in mice despite the model of acute inflammation used.

Key words: MRP-14; neutrophils; antinociception; carrageenan; mice.

\section{Neutrophils and the calcium-binding protein MRP-14 mediate carrageenan-induced antinociception in mice}

\author{
Rosana L. Pagano ${ }^{1}$, Maria Angela Amorim Dias², \\ Camila S. Dale ${ }^{1}$ and Renata Giorgi ${ }^{1, C A}$
}

${ }^{1}$ Laboratory of Pathophysiology, Butantan Institute, Av Vital Brazil, 1500, São Paulo, 05503-900 São Paulo, SP, Brazil; ${ }^{2}$ Discipline of Immunology, Federal University of São Paulo, São Paulo, SP, Brazil.

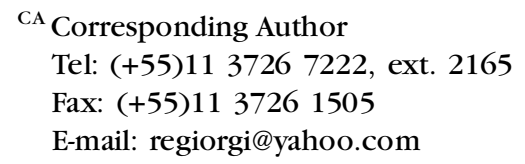

\section{Introduction}

Inflammation is initiated by release of pharmacological agents and consequent recruitment of leukocytes from the blood stream to the injured tissues. These events involve expression of adhesion molecules on the vascular endothelium and adherence, diapedesis, and emigration of leukocytes to the extra vascular compartments. ${ }^{1,2}$

In most of the animal models of inflammation, a high proportion of neutrophils and a low propor- tion of monocytes promptly arrive at the focus of injury. Besides its typical morphology, neutrophils can be characterized by the high expression of the calcium-binding proteins MRP-8 and MRP- $14 .^{3}$ These proteins were isolated, sequenced, and their genes cloned in an attempt to characterize the migration inhibitory factor (MIF) that accounts for their denomination as MIF-related proteins. ${ }^{4,5}$ These proteins belong to the S-100 protein family and form heterodimeric complexes called calprotectin. ${ }^{6,7}$ 
MRP-8 and MRP-14 proteins are also named L1 light and heavy chain, ${ }^{8,9}$ calgranulin $\mathrm{A}$ and $\mathrm{B},{ }^{10,11} \mathrm{p} 8$ and p $14^{12}$ respectively, and cystic fibrosis antigen. ${ }^{13}$ The expression of these proteins is restricted to a specific stage of myeloid differentiation, since both proteins are expressed in circulating neutrophils and monocytes but are absent in normal tissue macrophages and lymphocytes. ${ }^{14,15}$ MRP-8 and MRP-14 comprise 45 and $1 \%$ of the total proteins in the cytosol of neutrophils and monocytes respectively. ${ }^{16}$ Under inflammatory conditions and/or upon calcium mobilization they are translocated from the cytosol to the cytoskeleton and to cell plasma membrane. ${ }^{17,18}$ It has been demonstrated that both proteins are secreted by activated monocytes via a tubulin and Protein Kinase C-dependent pathway. ${ }^{19}$ Another relevant characteristic of these proteins is that they are highly conserved, presenting 60-80\% homology between humans, rat, and mouse. ${ }^{16,20}$ Recently, it has been demonstrated that the heterodimer of these proteins binds arachidonic acid with high affinity. ${ }^{21,22}$

A novel function recently described for MRP-14 is its ability to regulate neutrophil adhesion to fibrinogen via $\beta_{2}$ integrin (CD11b/CD18, Mac-1). ${ }^{23}$ MRP$8 / 14$ complex is found in high concentrations in body fluids of patients with acute and chronic diseases such as chronic bronchitis, cystic fibrosis and rheumatoid arthritis, ${ }^{24-26}$ suggesting a possible extracellular role for these proteins. In this context, it has been reported a marked anti-inflammatory effect of MRP8/14 complex in a model of adjuvant-induced arthritis in the rat. ${ }^{27}$ Additionally, it was demonstrated that the calcium-binding protein MRP-14 but not the MRP-8 deactivates activated peritoneal macrophages. ${ }^{28}$

It is generally accepted that neutrophils are at the forefront of an inflammatory response. These cells act not only as effector cells but also as regulatory cells in inflammatory reactions through the production of a variety of protein factors including proteolytic enzymes and cytokines. ${ }^{29-31}$ On the other hand macrophages, considered as the body's alarm cell, ${ }^{32}$ also secrete a large variety of chemical mediators released during the inflammatory response. ${ }^{33}$ It is also well established that mediators released by these cells can interfere in the pathophysiology of inflammatory pain. ${ }^{34,35}$

Among these chemical mediators witch regulate the inflammatory nociceptive response are $\mathrm{TNF}_{-} \alpha$, prostaglandins, interleukin (IL)-1, IL-6, IL-8 and others. ${ }^{36-37}$ Otherwise, it has also been demonstrated the participation of interleukins such as IL-4, IL-10 and IL-13 on inhibitory mechanisms of inflammatory hyperalgesia. ${ }^{38-40}$ In this context, results obtained in our laboratory demonstrated that the calcium-binding protein MRP-14 induces an antinociceptive effect when evaluated in a model of inflammatory pain in the mouse. ${ }^{41}$ We have also demonstrated that MRP-14 released by neutrophil mediates the inhibition of pain response in a model of neutrophilic peritonitis induced by glycogen in mice. ${ }^{41}$ In this paper we demonstrate that the intraperitoneal inoculation of a carrageenan $(\mathrm{Cg})$ solution in mice also induces antinociception. Thus, the aim of this work was to investigate the participation of both neutrophils and MRP-14 on Cg-induced antinociception, in an attempt to broaden the hypothesis that neutrophils, via MRP14 , is an endogenous antinociceptive component of the inflammatory response as previously suggested. ${ }^{41}$

\section{Materials and methods}

\section{Animals}

Outbreed male mice from the Swiss strain, weighing 20-25 g, were used throughout this study. The animals were maintained under controlled light (12/12 hours) and temperature $\left(22 \pm 2^{\circ} \mathrm{C}\right)$ with free access to food and water. Throughout the experiments, the animals were managed using the principles and guidelines for the care of laboratory animals according to Zimmermann. ${ }^{42}$

\section{Carrageenan-induced peritonitis}

Carrageenan (Sigma, MO, USA) was prepared in sterile saline $(300 \mu \mathrm{g} / 0.2 \mathrm{ml}$ per animal). Mice were injected intraperitoneally with $0.5 \mathrm{ml}$ of this solution and killed in an ether chamber after 0.5, 2, 4, 8, 12, 24 and $48 \mathrm{~h}$. The peritoneal exudate was collected and the total and differential counts of leukocytes determined. Controls were injected with sterile saline. Animals injected with $\mathrm{Cg}$ solution were submitted, after different time intervals, to the nociceptive test.

\section{Nociception evaluation by the writhing test}

The mouse writhing test used was based on the method of Koster et al. ${ }^{43}$ The abdominal contortions resulting from intraperitoneal (i.p.) injection of acetic acid (0,6\%; Merck, Darmstadt, Germany) at a dosage of $60 \mathrm{mg} / \mathrm{Kg}(\mathrm{v} / \mathrm{v})$ consist of a contraction of the abdominal muscles together with the stretching of the hind limb. The number of abdominal contortions was counted cumulatively over a period of $20 \mathrm{~min}$ after acetic acid injection. The antinociceptive activity was expressed as the reduction in number of abdominal contortions in treated as compared to control animals (injected only with acetic acid).

\section{Monoclonal antibodies (mAbs)}

Rat mAb (IgG2b) anti-granulocyte (anti-GR-1), an antibody that depletes mice of mature granulocytes, ${ }^{44}$ and rat $\mathrm{mAb}$ (IgG) anti-murine MRP-14 (EPM-1B4D3) were used. The antibody anti-Gr-1 $(0.25 \mathrm{mg}$ of protein 
in $500 \mu \mathrm{l}$ of saline) was injected i.p. $36 \mathrm{~h}$ before the i.p. injection of $\mathrm{Cg}$. The $\mathrm{mAb}$ anti-MRP-14 $(0.4 \mathrm{mg}$ of protein in $100 \mu$ l of saline) was injected intravenously $5 \mathrm{~min}$ before the phlogistic agent injection.

\section{Immunohistochemistry}

The animals injected or not with anti-granulocyte antibody were killed in an ether chamber $4 \mathrm{~h}$ after $\mathrm{Cg}$ injection. The peritoneal exudate was collected with $5 \mathrm{ml}$ of RPMI media and the peritoneal cells counted and concentrated to $2 \times 10^{6}$ cell/150 $\mu 1$ in RPMI media. Experiments were performed using 24-well plates (Costar, NY, USA) with sterile round glass coverslips in the bottom. The plates were incubated for $1 \mathrm{~h}$ at $37^{\circ} \mathrm{C}$ followed by lavage with phosphate-buffered saline (PBS) and fixation in Millonig fixative for $24 \mathrm{~h}$. In the moment of the assay, plates were washed for three times with PBS and incubated with glycine buffer $(50 \mathrm{mM})$ for $30 \mathrm{~min}$ at room temperature. Subsequently, the buffer was discarded, the wells washed with PBS and the cell membranes permeabilized with a Triton X-100 solution ( $0.02 \%)$ for $5 \mathrm{~min}$. All incubations were done at room temperature and PBS was used for washing the wells after each step. Endogenous peroxidase was quenched with $0.3 \% \mathrm{H}_{2} \mathrm{O}_{2}$ in PBS for $50 \mathrm{~min}$. The cells were then incubated with normal horse serum in PBS for $1 \mathrm{~h}$ and overlaid with the primary antibody (mAb anti-MRP-14) at $4^{\circ} \mathrm{C}$ overnight. Thereafter they were incubated with biotinylated goat anti-rat IgG secondary antibody (Sigma, MO, USA), followed by streptoavidin peroxidase complex (Sigma, MO, USA) for $30 \mathrm{~min}$. The material was stained with $10 \mathrm{mg}$ of diaminobenzidine tethahydrochlorid (DAB; Sigma, MO, USA) with $0.03 \% \mathrm{H}_{2} \mathrm{O}_{2}$ in Tris-buffered saline $(0,05 \mathrm{M} ; \mathrm{pH} 7,6)$. After staining, the cells were washed in tap water and counterstained with Harry's hematoxilin (Merck, Darmstadt, Germany) for $40 \mathrm{sec}$. Finally, the cells were dehydrated and mounted in Entellan (Merck, Darmstadt, Germany).

\section{Participation of opioids}

Mice were injected with naloxone chloridate (Rhodia, São Paulo, Brasil), a universal opioid antagonist, prepared in sterile saline $(1 \mathrm{mg} / \mathrm{Kg}$ per animal). Animals were injected with $200 \mu 1$ of this solution by subcutaneous route $15 \mathrm{~min}$ before the i.p. injection of acetic acid in animals pretreated with $\mathrm{Cg}$.

\section{Participation of glucocorticoids}

Mice were injected with metyrapone (Ciba-Geigy, São Paulo, Brazil), dissolved in sterile saline. Metyrapone blocks the synthesis of glucocorticoids without causing a typical deficiency of mineralocorticoids. ${ }^{45}$ Two daily doses of $30 \mathrm{mg} / \mathrm{Kg}$ each were given intraperitoneally at $12 \mathrm{~h}$ intervals for 5 days. ${ }^{46}$ Control
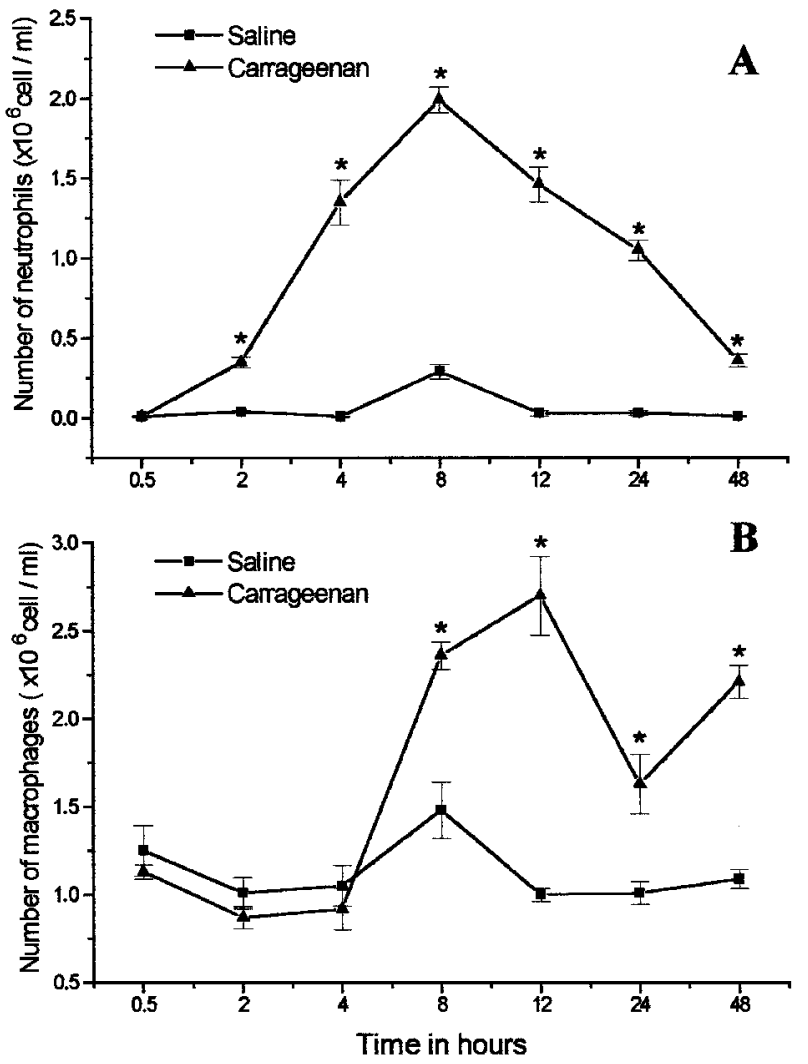

FIG. 1. Kinetic of leukocyte influx to peritoneal cavity of mice after i.p. injection of a carrageenan $(\mathrm{Cg})$ solution $(300 \mu \mathrm{g} / 0,2 \mathrm{ml}$ per animal). Number of neutrophils in the peritoneal cavity after the irritant injection (A). Number of mononuclear cells after $\mathrm{Cg}$ injection (B). The results are expresses in absolute numbers obtained in relation to the total number of collected cells. Data represent mean values \pm S.E.M. for 8-16 animals for each experimental time. * Significantly different from mean values of saline group ( $p$ $<0.05)$.

animals received the same amount of saline. $\mathrm{Cg}$ injection was made $2 \mathrm{~h}$ after the administration of the last dose metyrapone and the writhing test evaluated $4 \mathrm{~h}$ after injection of the phlogistic agent.

\section{Statistical analysis}

Results are expressed as mean \pm standard errors of means (S.E.M.) and were compared by the Student'st test or by analysis of variance ${ }^{47}$ followed by Duncan's test. ${ }^{48} \mathrm{~A}$ probability level of less than 0.05 was taken as significant $(p<0.05)$.

\section{Results}

\section{Leukocyte migration induced by carrageenan}

Considering that the protein MRP-14 is expressed in large amounts in the cytosol of neutrophils ${ }^{16}$ and that this protein mediates an antinociceptive effect in a neutrophilic peritonitis induced by glycogen, ${ }^{41}$ we decided to investigate if this effect was restricted to the glycogen model or if it could be evidenced in an 


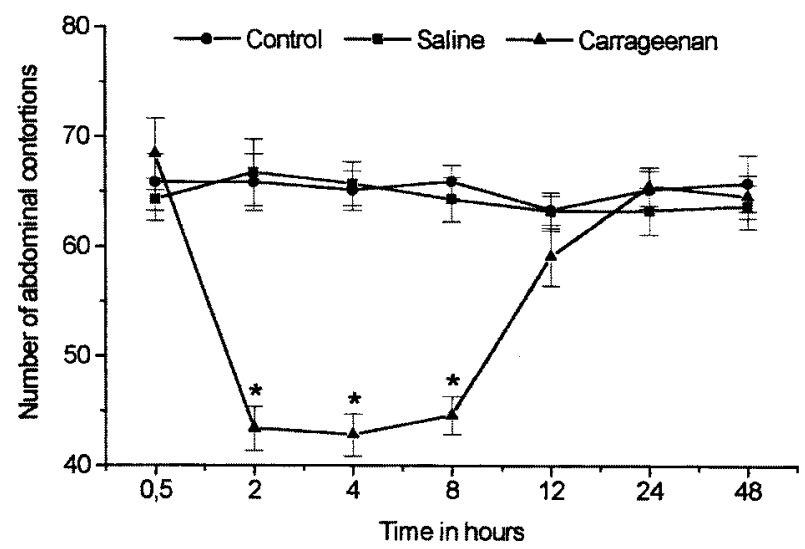

FIG. 2. Effect of carrageenan $(\mathrm{Cg})$ on painful sensibility of mice evalued in the writhing test. The test was applied in different times after the i.p. injection of $\mathrm{Cg}(300 \mu \mathrm{g} / 0,2 \mathrm{ml}$ per animal). Controls were injected only with acetic acid. Values represent the mean \pm S.E.M. of 8-16 animals for each group. ${ }^{*} p<0.05$ in comparison with values obtained in control animals.

another model of neutrophilic peritonitis. For this purpose a model of neutrophilc peritonitis was established using $\mathrm{Cg}$ as the phlogistic agent.

Results show that the i.p. injection of this irritant evokes significant alterations in the pattern of circulating leukocytes. The total number of neutrophils in the peritoneal cavity of animals injected with $\mathrm{Cg}$ was significantly higher than controls. The maximal number of polymorphonuclear cells in the peritoneal cavity was observed $8 \mathrm{~h}$ after the irritant injection (Fig. 1A). On the other hand, a marked increase in the number of mononuclear cells $8 \mathrm{~h}$ after the phlogistic agent injection was observed (Fig. 1B).

\section{Carrageenan-induced neutrophilic peritonitis and antinociception evaluated by the writhing test}

To investigate a possible correlation between the influx of neutrophils to the peritoneal cavity and a possible antinociceptive effect of the irritant, animals were submitted to the writhing test after $\mathrm{Cg}$ injection. As show in Figure 2, mice injected with $\mathrm{Cg}$ and tested after 2, 4 or $8 \mathrm{~h}$ in the pain test showed a significant decrease in the number of abdominal contortions when compared with animals previously injected with saline or with acetic acid alone. $( \pm 30 \%$ inhibition in all the times tested).

\section{Effect of mAb anti-granulocyte on}

antinociception in the carrageenan-induced peritonitis

To investigate whether the analgesic effect observed was due to the presence of neutrophils in the inflammatory site, depletion of these cells with a specific mAb was used. Animals pretreated with mAb

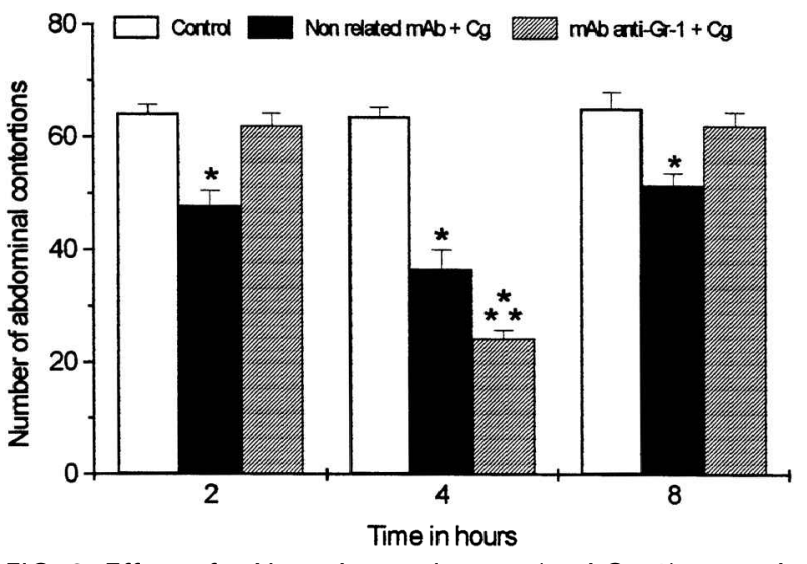

FIG. 3. Effect of mAb anti-granulocytes (anti-Gr-1) on antinociception induced by carrageenan $(\mathrm{Cg})$ in animals submitted to the writhing test. The mAb anti-Gr-1 was injected $36 \mathrm{~h}$ before the i.p. injection of $\mathrm{Cg}$ and 2, 4 or $8 \mathrm{~h}$ later submitted to the writhing test. Animals injected with non related $\mathrm{mAb}$ were also evaluated. Controls were injected only with acetic acid. Values represent the mean \pm S.E.M. of 8-16 animals for each group. ${ }^{*} p<0.05$ in comparison with values obtained in control animals. ${ }^{*} p<0.05$ in comparison with the group treated with non related $\mathrm{mAb}+\mathrm{Cg}$.

anti-granulocyte (anti-Gr-1, $0.25 \mathrm{mg}$, i.p.), $36 \mathrm{~h}$ before the i.p. injection of $\mathrm{Cg}$, showed a $99 \%$ reduction in the total number of neutrophils in the peritoneal exudate (data not shown). Depletion of neutrophils, totally reverted the antinociceptive response only after 2 and $8 \mathrm{~h}$ of the irritant injection (Fig. 3). In contrast, this treatment enhanced the antinociceptive effect at $4 \mathrm{~h}$ after $\mathrm{Cg}$ injection. The treatment of animals with non-related rat IgG2b did not influence the antinociceptive effect observed in any times after the irritant injection (Fig. 3).

\section{Effect of mAb anti-MRP-14 on the antinociceptive response induced by carrageenan}

To investigate whether MRP-14 was implicated in the antinociception observed, mice were treated with$\mathrm{mAb}$ anti-MRP-14. The animals were treated with $40 \mu \mathrm{g}$ of protein in $50 \mu 1$ saline, i.v., $5 \mathrm{~min}$ before the i.p. injection of $\mathrm{Cg}$. This treatment completely abolished antinociception detected 2 and $8 \mathrm{~h}$ after the irritant injection (Fig. 4). However, this treatment only partially reverted antinociception observed after $4 \mathrm{~h}$ of $\mathrm{Cg}$ injection. Treatment of animals with nonrelated rat IgG had no effect in the antinociceptive effect induced by this irritant (Fig. 4).

\section{Simultaneous treatment of the animals with anti-granulocyte and anti-MRP-14 mAbs}

Once the depletion of neutrophils enhances the antinociceptive response when the test were applied $4 \mathrm{~h}$ after $\mathrm{Cg}$ injection, we decided to evaluate the response of the animals in the absence of neutrophils 


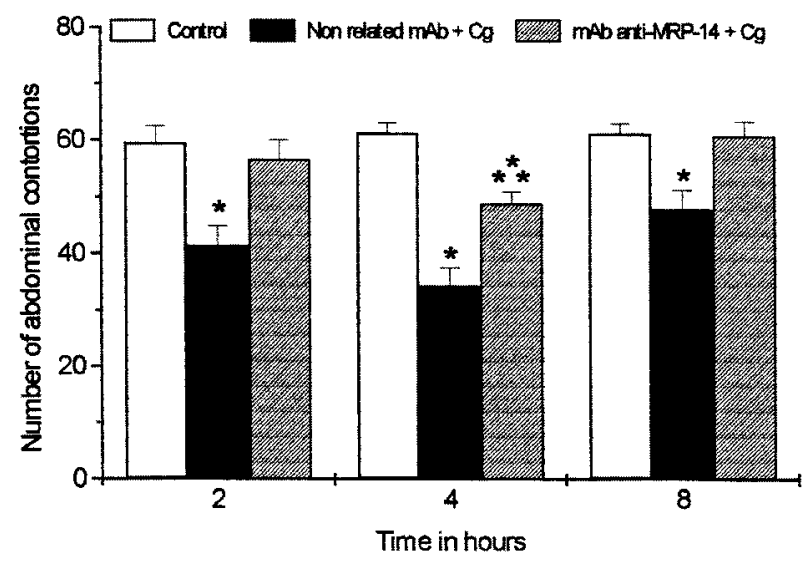

FIG. 4. Effect of mAb anti-MRP-14 on antinociception induced by carrageenan $(\mathrm{Cg})$ in animals submitted to the writhing test. The mAb anti-MRP-14 was injected 5 min before the i.p. injection of $\mathrm{Cg}$ and 2, 4 or $8 \mathrm{~h}$ later submitted to the writhing test. Animals injected with non-related $\mathrm{mAb}$ were also evaluated. Controls were injected only with acetic acid. Values represent the mean \pm S.E.M. of 8-16 animals for each group. ${ }^{*} p<0.05$ in comparison with values obtained in control animals. ${ }^{* *} p<0.05$ in comparison with the group treated with non related $\mathrm{mAb}+\mathrm{Cg}$.

and MRP-14. Mice were inoculated with mAb antigranulocyte $36 \mathrm{~h}$ before treatment with the mAb antiMRP-14. The Cg solution was injected 5 min after the last treatment and the writhing test applied $4 \mathrm{~h}$ after the phlogistic agent injection. Results show that treatment with both antibodies abolished the potentialization of antinociceptive effect induced by $\mathrm{Cg}$ in animals pretreated with antibody anti-granulocyte (Fig. 5). Treatment of animals with non-related mAbs

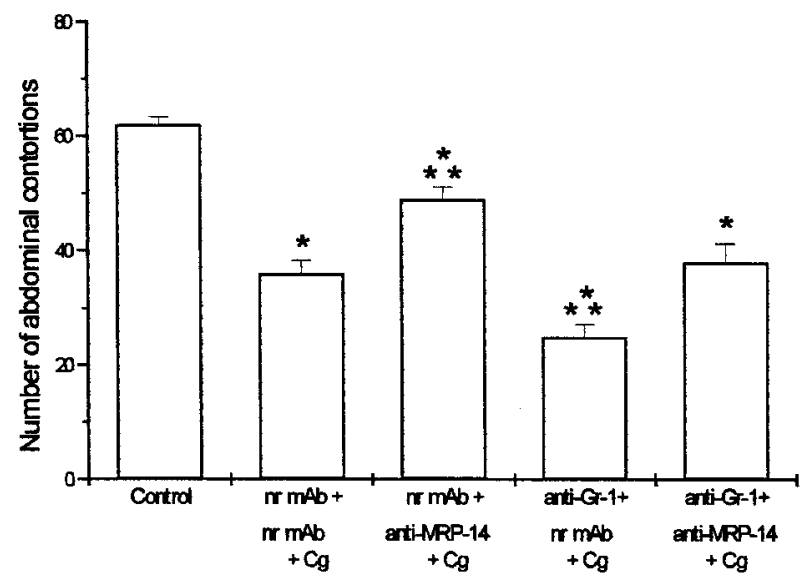

FIG. 5. Effect of simultaneous treatment of the animals with anti-granulocyte (anti-Gr-1) and anti-MRP-14 mAbs on antinociception induced by carrageenan $(\mathrm{Cg})$ in animals submitted to the writhing test. The mAb anti-Gr-1 was injected $36 \mathrm{~h}$ before the irritant and the anti-MRP-14 was injected 5 min before the injection of $\mathrm{Cg}$. The nociceptive test was applied $4 \mathrm{~h}$ after $\mathrm{Cg}$ injection. Animals injected with non related $m A b s$ ( $n r m A b s)+C g, n r m A b+$ anti-MRP- $14+\mathrm{Cg}$ or $\mathrm{nr} \mathrm{mAb}+$ anti-Gr-1 + Cg were also evaluated. Controls were injected with acetic acid. Values represent the mean \pm S.E.M. of 8-16 animals for each group. ${ }^{*} p<0.05$ in comparison with values obtained in control animals. ${ }^{* *} p<0.05$ in comparison with animals treated with $\mathrm{nr}$ mAbs $+\mathrm{Cg}$. did not alter the antinociceptive response evaluated $4 \mathrm{~h}$ after the irritant injection (Fig.5).

\section{Detection of MRP-14 in peritoneal cells of animals inoculated with carrageenan}

Considering that the treatment with mAb anti-MRP-14 was able to revert the potentialization of antinociceptive effect observed $4 \mathrm{~h}$ after the $\mathrm{Cg}$ injection in animals depleted of neutrophils, the expression of MRP-14 in other inflammatory cells was evaluated by imunocitochemistry. Cells were obtained from the abdominal cavity of animals $4 \mathrm{~h}$ after the irritant injection in mice pretreated or not with anti-granulocyte mAb. Cells obtained from the peritoneal exudate $4 \mathrm{~h}$ after $\mathrm{Cg}$ injection were positive for MRP-14 protein (Fig. 6A). However, when the test was made with cells obtained from the peritoneal exudate $4 \mathrm{~h}$ after the irritant injection in mice depleted of neutrophils, the expression of MRP-14 was significantly more intense. A larger number of cells expressing the protein in their cytoplasm was observed (Fig. 6B).
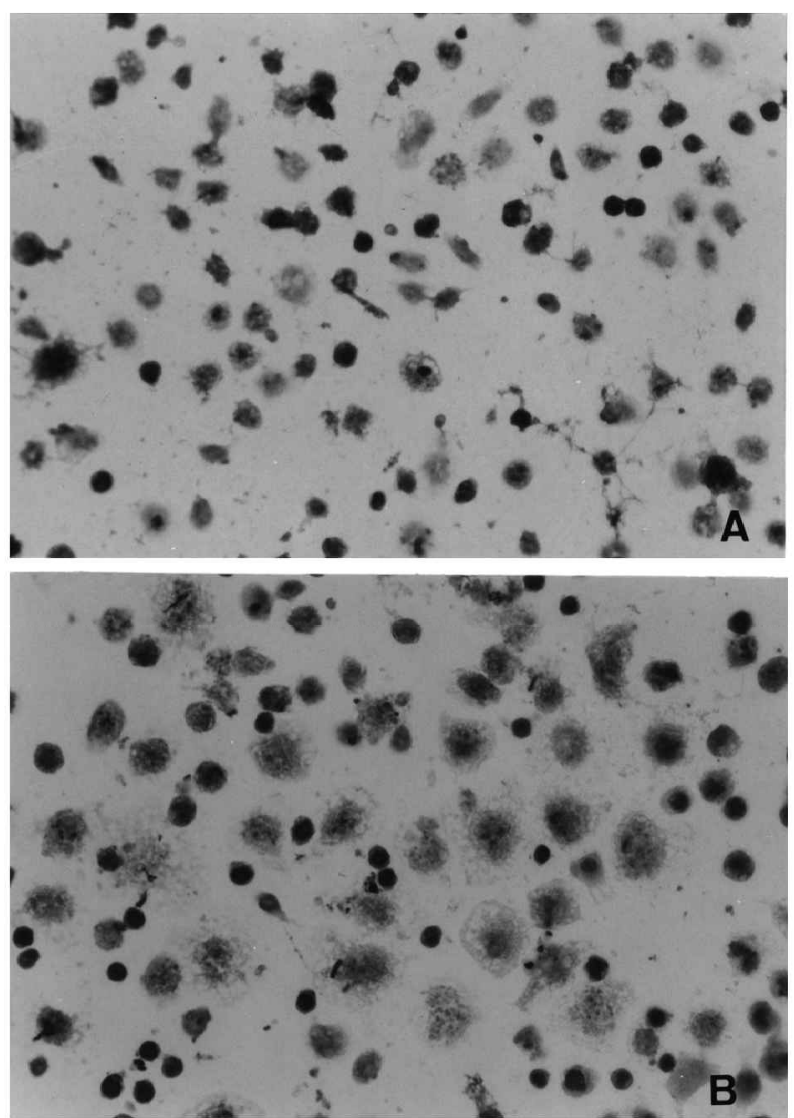

FIG. 6. Photomicrography of cells obtained from the peritoneal cavity of animals injected with $\mathrm{Cg} 4 \mathrm{~h}$ before and immunostained for the calcium-binding protein MRP-14 (A). In $B$, cells obtained from the peritoneal exudate induced by $\mathrm{Cg}$ injection in an animal previously depleted of neutrophils. The expression of MRP-14 is more intense in this preparation. Optic microscopy $(\times 100)$. 
Participation of endogenous opioids on antinociception induced by carrageenan

Once the mAbs anti-granulocyte and anti-MRP-14 did not totally revert the antinociceptive effect induced $4 \mathrm{~h}$ after $\mathrm{Cg}$ injection, the possible participation of endogenous opioids in the phenomenon was evaluated. Animals were treated with naloxone chloridate $15 \mathrm{~min}$ before the nociceptive test in mice pretreated 2 or $4 \mathrm{~h}$ with $\mathrm{Cg}$. Results demonstrated that opioid peptides did not influence the antinociception induced by $\mathrm{Cg}$ (data not shown).

\section{Participation of glucocorticoids in the antinociceptive effect evoked by carrageenan}

The participation of glucocorticoids, other possible endogenous factor important on the control of inflammatory pain, was evaluated during antinociception induced $4 \mathrm{~h}$ after $\mathrm{Cg}$ injection. Pretreatment of animals with metyrapone, an inhibitor of glucocorticoid synthesis, given intraperitoneally in two daily doses (12/12h) for 5 days, did not alter the antinociceptive effect induced by $\mathrm{Cg}$ (data not shown).

\section{Discussion}

As reported in the literature, chemical mediators released during the inflammatory process are endowed with the property of inhibiting pain response. It has been shown that interleukins such IL4, IL-10 and IL-13 have the propriety to limit inflammatory hiperalgesia by blocking the release of pro-inflammatory cytokines by inflammatory cells. ${ }^{38-40}$ Furthermore, it was demonstrated by Giorgi et al. ${ }^{41}$ that the calcium-binding protein MRP14 has a marked antinociceptive activity in an inflammatory pain model in mice. These authors brought evidences that neutrophils participate in the control of inflammatory pain by secreting this protein to the inflammatory milieu. ${ }^{41}$ Reports made by these authors however, were limited to a model of neutrophilic peritonitis induced by glycogen. It remains then to be investigated whether neutrophils and MRP14 also control inflammatory pain in other models of neutrophilic peritonitis. Here we demonstrate that similarly to the glycogen model, the intraperitoneal inoculation of carrageenan $(\mathrm{Cg})$ in mice not only induces a typical neutrophilic peritonitis but also a marked antinociceptive response when animals were tested in a model of inflammatory pain. The intraperitoneal injection of $\mathrm{Cg}$ solution 2,4 or $8 \mathrm{~h}$ before the acetic acid inoculation induces a significant antinociceptive response. Interesting to note that at these times a large number of neutrophils were found in the peritoneal cavity of the animals.
Based on these observations we investigated the possible participation of neutrophils and of the calcium-binding protein MRP-14 in the antinociception induced by $\mathrm{Cg}$. Results showed that treatment of animals with mAbs anti-granulocyte or anti-MRP14 before the phlogistc agent administration were able to totally revert antinociception observed 2 and $8 \mathrm{~h}$ after $\mathrm{Cg}$ injection. Unexpectedly, pretreatment of animals with anti-granulocyte $\mathrm{mAb}$ induced an increase in the antinociceptive effect observed $4 \mathrm{~h}$ after the irritant injection. Further, the treatment of animals with anti-MRP-14 mAb partially reverted antinociception observed $4 \mathrm{~h}$ after the irritant injection. Based on these observations, animals were treated with both antibodies previously to the evaluation of the antinociceptive response. The association of antibodies anti-granulocyte and anti-MRP-14 induced the reversion of increase in antinociceptive effect observed when the animals were treated only with the anti-granulocyte $\mathrm{mAb}$ followed by $\mathrm{Cg}$ injection.

Amorim Dias (personal communication, 2002) have demonstrated that the intraperitoneal inoculation glycogen in granulocyte-depleted mice induces the expression of MRP-14 in the cytoplasm of mononuclear cells. Similarly, mononuclear cells obtained from the peritoneal cavity of neutropenic mice injected with $\mathrm{Cg}$ also express the calciumbinding protein MRP-14. Thus, these data suggest that the enhancement of the antinociceptive effect observed after treatment of the animals with antigranulocyte antibody might be due to secretion of MRP-14 by macrophages. However, the mechanisms by which neutrophil depletion induces macrophages to express the protein MRP-14 remains to be investigated.

Since antinociception observed $4 \mathrm{~h}$ after $\mathrm{Cg}$ injection was not totally reverted by treatment of animals with anti-MRP-14 antibody, other endogenous factors could be involved in the inhibition of pain sensibility. The liberation of endogenous opioids after $\mathrm{Cg}$ injection might be one of these factors. It has been largely demonstrated that endogenous opioids participate in control of inflammatory pain. ${ }^{49-50}$ Our results however, showed that these mediators seems not to be involved in the antinociception observed at the $4^{\text {th }}$ hour after $\mathrm{Cg}$ injection since treatment of the animals with naloxone did not alter this effect. As has been demonstrated, $\mathrm{Cg}$ can activate the hypothalamus-adrenal axis inducing the release of glucocorticoids by the adrenal gland. ${ }^{51}$ As reported in the literature, this hormone is endowed with a potent anti-inflammatory activity and consequently, an analgesic property. ${ }^{52-54}$ Our data demonstrate that an exacerbation in the release of glucocorticoids by adrenal glands, seems not to influence antinociception in this model since the inhibition of glucocorticoid synthesis by metyrapone administration did not interfere with the antinociceptive 
response. Thus, besides the partial mediation of MRP-14 in the antinociceptive effect observed after $4 \mathrm{~h}$ of $\mathrm{Cg}$ injection other mechanisms involved in this effect remains to be elucidated. In summary, results obtained in this work demonstrate that neutrophils and the calcium-binding protein MRP-14 participate in the endogenous control of the inflammatory pain in mice despite the model of acute inflammation used.

ACKNOWLEDGEMENTS. This study was part of the Master Dissertation presented by Rosana L. Pagano, developed at the Department of Pathology, School of Veterinary Medicine, University of São Paulo, Brazil, area of Experimental and Comparative Pathology. We are indebted to Dr. Sandra S.P. Farsky for metyrapone, and Dr. Mario Mariano and Marcelo L. Santoro for critical review of the manuscript. Financial support by FAPESP and Funda ão Butantan.

\section{References}

1. Beekhuizen H, van Furth R. Monocyte adherence to human endothelium. J Leuk Biol 1993; 54: 363-78.

2. Downey GP, Fialkow L, Fukushima T. Initial interaction of leukocytes within the microvasculature: deformability, adhesion, and transmigration. New Horiz 1995; 3: 219-28.

3. Roth J, Sunderkotter C, Goebeler M, Gutwald J, Sorg C. Expression of the calcium-binding proteins MRP8 and MRP14 by early infiltrating cells in experimental contact dermatitis. Int Arch Allergy Apll Immunol 1992; 98: $140-5$.

4. Odink K, Cerletti N, Bruggen J, Clerc RG, Tarcsay L, Zwadlo G, Gerhards G, Schlegel R, Sorg C. Two calcium-biding proteins in infiltrate macrophages of rheumatoid arthritis. Nature 1987; 330: 80-2

5. Hessian PA, Edgeworth J, Hogg N. MRP-8 and MRP-14, two abundant $\mathrm{Ca}^{2+}$-binding proteins of neutrophils and monocytes. J Leuk Biol 1993; 53: 197-204

6. Kligman D, Hilt DC. The S100 protein family. TIBS 1988; 13: 437-43.

7. Steinbakk M, Naess-Andresen CF, Lingaas E, Dale I, Brandtzaeg P, Fagerhol MK Antimicrobial actions of calcium binding leucocyte L1 protein, calprotectin. Lancet 1990; 336: 763-5.

8. Dale I, Fagerhol MK, Naesgaard I. Purification and partial characterization of a highly immunogenic human leukocyte protein, the L1 antigen. Eur J Biochem 1983; 134: 1-6.

9. Andersson KB, Sletten K, Berntzen HB, Dale I, Brandtzaeg P, Jellum E, Fagerhol MK. The leukocyte L1 protein: identity with the cystic fibrosis antigen and the calcium-binding MRP-8 and MRP-14 macrophage components. Scand J Immunol 1988; 28: 241-5.

10. Wilkinson MM, Busutti A, Hayward C, Brock DJ, Dorin JR, van Heyningen V. Expression pattern of two related cystic fibrosis-associated calcium binding proteins in normal and abnormal tissues. J Cell Sci 1988; 91: 221-30.

11. Kelly SE, Jones DB, Fleming S. Calgranulin expression in inflammatory dermatoses. I Pathol 1989; 159: 17-21.

12. Hogg N, Allen C, Edgeworth J. Monoclonal antibody 5.5 reacts with p8,14, a myeloid molecule associated with some vascular endothelium Eur J Immunol 1989; 19: 1053-61.

13. Dorin JR, Novak M, Hill RE, Brock DJH, Secher DS, van Heyningen V. A clue to the basic defect in cystic fibrosis from cloning the $\mathrm{CF}$ antigen gene. Nature 1987; 326: 614-7.

14. Zwadlo G, Bruggen J, Gerhards G, Schlegel R, Sorg C. Two calciumbinding proteins associated with specific stages of myeloid cell differentiation are expressed by subsets of macrophages in inflammatory tissues. Clin Exp Immunol 1988; 72: 510-5.

15. Lagasse E, Clerc RG. Cloning and expression of two human genes encoding calcium-binding proteins that are regulated during myeloid differentiation. $\mathrm{Mol}$ Cell Biol 1988; 8: 2402-10.

16. Edgeworth J, Gorman M, Bennett R, Freemont P, Hogg N. Identification of $\mathrm{p} 8,14$ as a highly abundant heterodimeric calcium binding protein complex of myeloid cells. J Biol Chem 1991; 266: 7706-13.

17. Roth J, Burwinkel F, van den Bos C, Goebeler M, Vollmer E, Sorg C. MRP8 and MRP14,S-100-like proteins associated with myeloid differentiation, are translocated to plasma membrane and intermediate filaments in a calcium-dependent manner. Blood 1993; 82: 1875-83.

18. van den Bos C, Roth J, Koch HG, Hartmann M, Sorg C. Phosphorylation of MRP14, an S100 protein expressed during monocytic differentiation, modulates $\mathrm{Ca}^{2+}$-dependent translocation from cytoplasm to membranes and cytoskeleton. J Immunol 1996; 156: 1247-54.

19. Rammes A, Roth J, Goebeler M, Klempt M, Hartmann M, Sorg C. Myeloidrelated protein (MRP) 8 and MRP14, calcium-binding proteins of the S100 family, are secreted by activated monocytes via a novel, tubulindependent pathway. J Biol Chem 1997; 272: 9496-502.
20. Nacken W, Sopalla C, Propper C, Sorg C, Kerkhoff C. Biochemical characterization of the murine S100A9 (MRP14) protein suggests that it is functionally equivalent to its human counterpart despite its low degree of sequence homology. Eur J Biochem 2000; 267: 560-5.

21. Klempt M, Melkonyan H, Nacken W, Wiesmann D, Holtkemper U, Sorg C. The heterodimer of the $\mathrm{Ca}^{2+}$-binding proteins MRP8 and MRP14 binds arachidonic acid. FEBS 1997; 408: 81-4.

22. Siegenthaler G, Roulin K, Chatellard-Gruaz D, Hotz R, Saurat JH, Hellman U, Hagens G. A heterocomplex formed by the calcium-binding proteins MRP8 (S100A8) and MRP14 (S100A9) binds unsaturated fatty acids with high affinity. $J$ Biol Chem 1997; 272: 9371-7.

23. Newton RA, Hogg N. The human S100 protein MRP-14 is a novel activator of the beta 2 integrin Mac- 1 on neutrophils. J Immunol 1998; 160: $1427-35$

24. Sorg C. The calcium binding proteins MRP8 and MRP14 in acute and chronic inflammation. Bebring Inst Mitt 1992; 91: 126-37.

25. Brun JG, Jonsson R, Haga HJ. Measurement of plasma calprotectin as an indicator of arthritis and disease activity in patients with inflammatory rheumatic diseases. J Rbeumatol 1994; 21: 733-8.

26. Golden BE, Clohessy PA, Russell G, Fagerhol MK. Calprotectin as a marker of inflammation in cystic fibrosis. Arch Dis Child 1996; 74 : 136-9.

27. Brun JG, Haland G, Haga HJ, Fagerhol MK, Jonsson R. Effects of calprotectin in avridine-induced arthritis. APMIS 1995; 103: 233-40.

28. Aguiar-Passeti T, Postol E, Sorg C, Mariano M. Epithelioid cells from foreign-body granuloma selectively express the calcium-binding protein MRP-14, a novel down-regulatory molecule of macrophage activation. $J$ Leuk Biol 1997; 62: 852-8.

29. McColl SR, Showell HJ. Neutrophil-derived inflammatory mediators. In Hellewell PG, Williams TJ, editors. Immunopharmacology of Neutrophils, Academic Press; 1994. p. 95-114.

30. Lloyd AR, Oppenheim JJ. Poly's lament: the neglected role of the polymorphonuclear neutrophil in the afferent limb of the immune response. Immunol Today 1992; 13: 169-72.

31. Cassatella MA. The production of cytokines by polymorphonuclear neutrophils. Immunol Today 1995; 16: 21-6.

32. Ferreira SH. Are macrophages the body's alarm cells? Agents Actions 1980; 10: 229-30.

33. Takemura R, Werb Z. Secretary products of macrophages and their physiological functions. Am J Physiol 1984; 246: C1-9.

34. Thomazzi SM, Ribeiro RA, Campos DI, Cunha FQ, Ferreira SH. Tumor necrosis factor, interlukin -1 and interleukin -8 mediate the nociceptive activity of the supernatant of LPS-stimulated macrophages. Med Inflamm 1997; 6: 195-200.

35. Ribeiro RA, Vale ML, Thomazzi SM, Paschoalato AB, Poole S, Ferreira SH, Cunha FQ. Involvement of resident macrophages and mast cells in the writhing nociceptive response induced by zymosan and acetic acid in mice. Eur J Pharmacol 2000; 387: 111-8.

36. Dray A, Bevan S. Inflammation and hyperalgesia: highlighting the team effort. TIPS 1993; 14: 287-90.

37. Dray A. Inflammatory mediators of pain. Br J Anaesth 1995; 75 $125-31$

38. Cunha FQ, Poole S, Lorenzetti BB, Veiga FH, Ferreira SH. Cytokinemediated inflammatory hyperalgesia limited by interlukin-4. $\mathrm{Br} J$ Pharmacol 1999; 126: 45-50.

39. Poole S, Cunha FQ, Selkirk S, Lorenzetti BB, Ferreira SH. Cytokinemediated inflammatory hyperalgesia limited by interleukin-10. $\mathrm{Br} J$ Pharmacol 1995; 115: 684-8.

40. Lorenzetti BB, Poole S, Veiga FH, Cunha FQ, Ferreira SH. Cytokinemediated inflammatory hyperalgesia limited by interleukin-13. Eur Cytokine Netw 2001; 12: 260-7.

41. Giorgi R, Pagano R, Amorim Dias MA, Aguiar-Passseti T, Sorg C, Mariano $M$. Antinociceptive effect of calcium-binding protein MRP-1 4 and the role played by neutrophils on the control of inflammatory pain. J Leuk Biol 1998; 64: 214-20.

42. Zimmermann M. Ethical guidelines for investigations of experimental pain in conscious animals. Pain 1983; 16: 109-10.

43. Koster R, Anderson M, de Beer EJ. Acetic acid for analgesic screening. Fed Proc 1959; 18: 412 .

44. Fleming TJ, Fleming ML, Malek TR. Selective expression of Ly-6G on myeloid lineage cells in mouse bone marrow. RB6-8C $5 \mathrm{mAb}$ to granulocyte-differentiation antigen (Gr-1) detects members of the Ly-6 family. J Immunol 1993; 151: 2399-408.

45. Temple TE, Liddle GW. Inhibitors of adrenal steroids biosynthesis. Annu Ver Pharmacol Toxicol 1970; 10: 199-218.

46. Sannomiya P, Anteghini HJ, Vianna ES, Garcia-Leme J. Involvement of lymphocytes in non-immune inflammation: dual effect of glucocorticoids. Agents Actions 1985; 16: 552-7.

47. Snedecor GW,. Statistical Methods. 4th ed. Ames, Iowa, State University Press, 1974.

48. Duncan DB. Multiple range and multiple F tests. Biometrics 1955; 11 $1-42$.

49. Czlonkowski A, Stein C, Herz A. Peripheral mechanisms of opioid antinociception in inflammation: involvement of cytokines. Eur Pharmacol 1993; 242: 229-35.

50. Stein C. The control of pain in peripheral tissue by opioids. $N$ Engl J Med 1995; 332: $1685-90$ 
51. Garcia Leme J, Schapoval EES. Stimulation of the hypothalamo-pituitaryadrenal axis by compounds formed in inflamed tissue. Br J Pharmac 1975; 53: $75-83$

52. Garcia Leme J, Farsky SP. Hormonal control of inflammatory responses. Med Inflamm 1993; 2: 181-98.

53. Chrousos GP. The hypothalamic-pituitary-adrenal axis and immunemediated inflammation. $N$ Engl J Med 1995; 332: 1351-62.

54. Schimmer BP, Parker KL. Adrenocorticotropic hormone; adrenocortical steroids and their synthetic analogs; inhibitors of the synthesis and actions of adrenocortical hormones. In: Hardman JG, Limbird LE, Molinoff PB, Ruddon RW, Gilman AG, editors. Goodman \& Gilman's. The Pharmacological Basis of Therapeutics. 10nd ed. New York, Mc Graw Hill; 2001. p. 1649-77.

Received 19 March 2002

Accepted 2 April 2002 


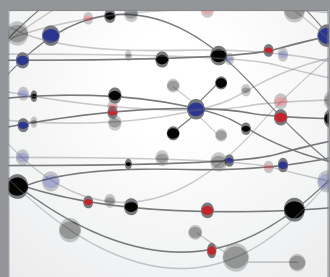

The Scientific World Journal
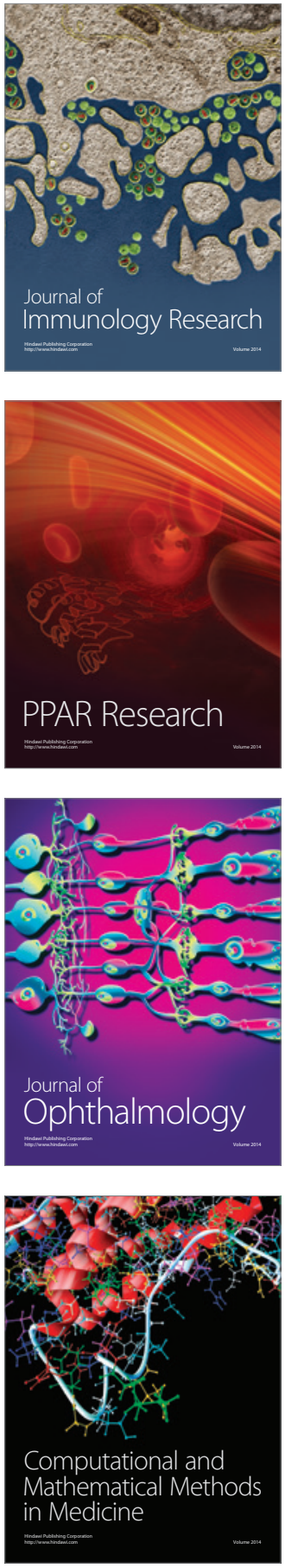

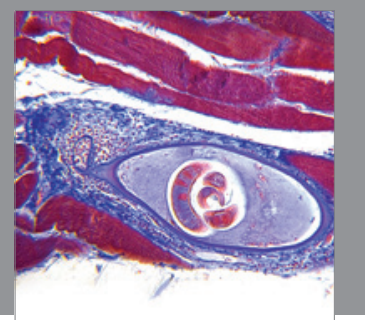

Gastroenterology

Research and Practice
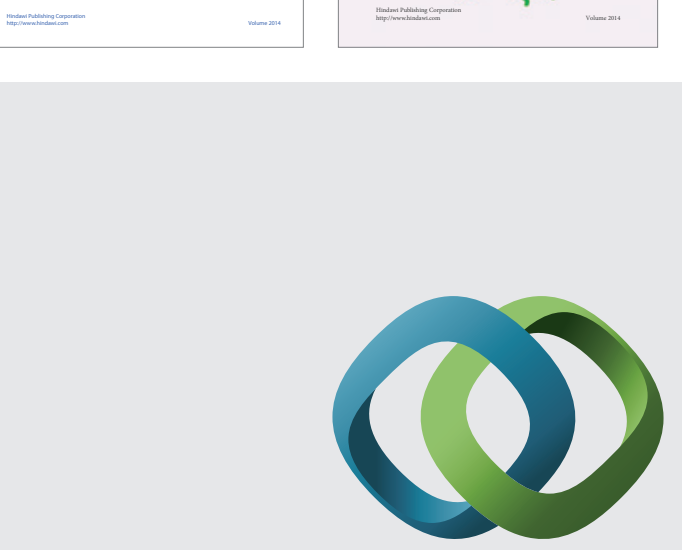

\section{Hindawi}

Submit your manuscripts at

http://www.hindawi.com
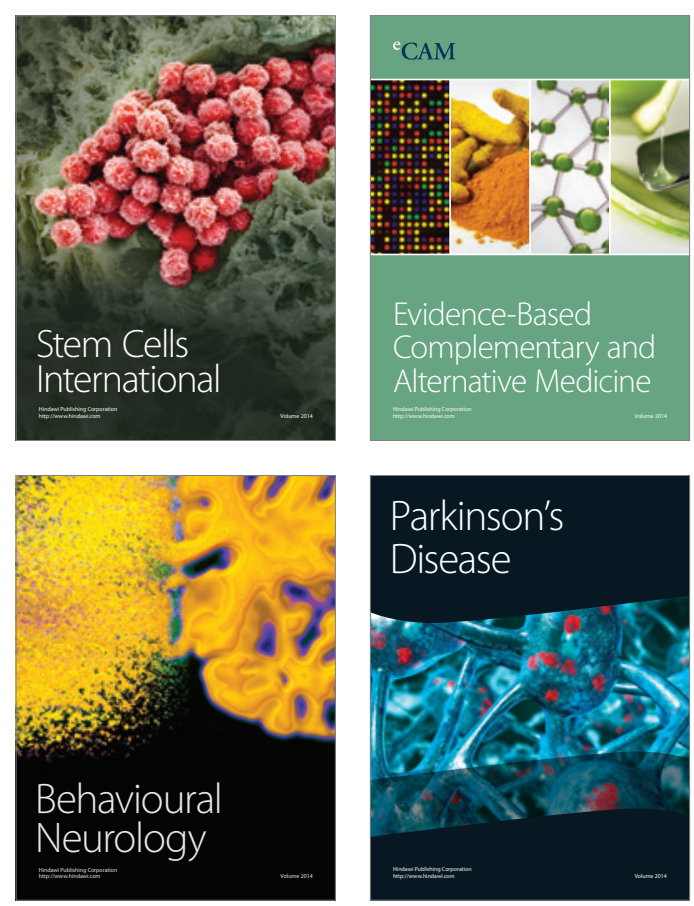

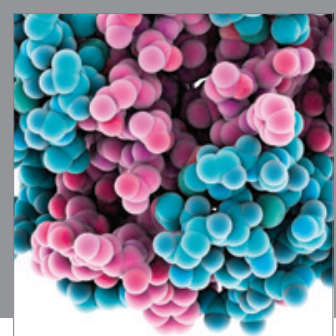

Journal of
Diabetes Research

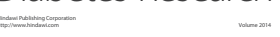

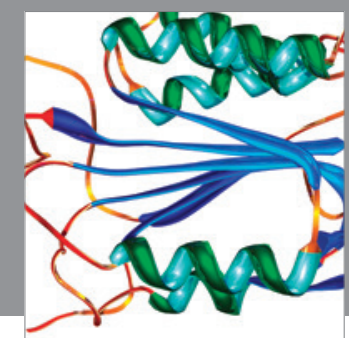

Disease Markers
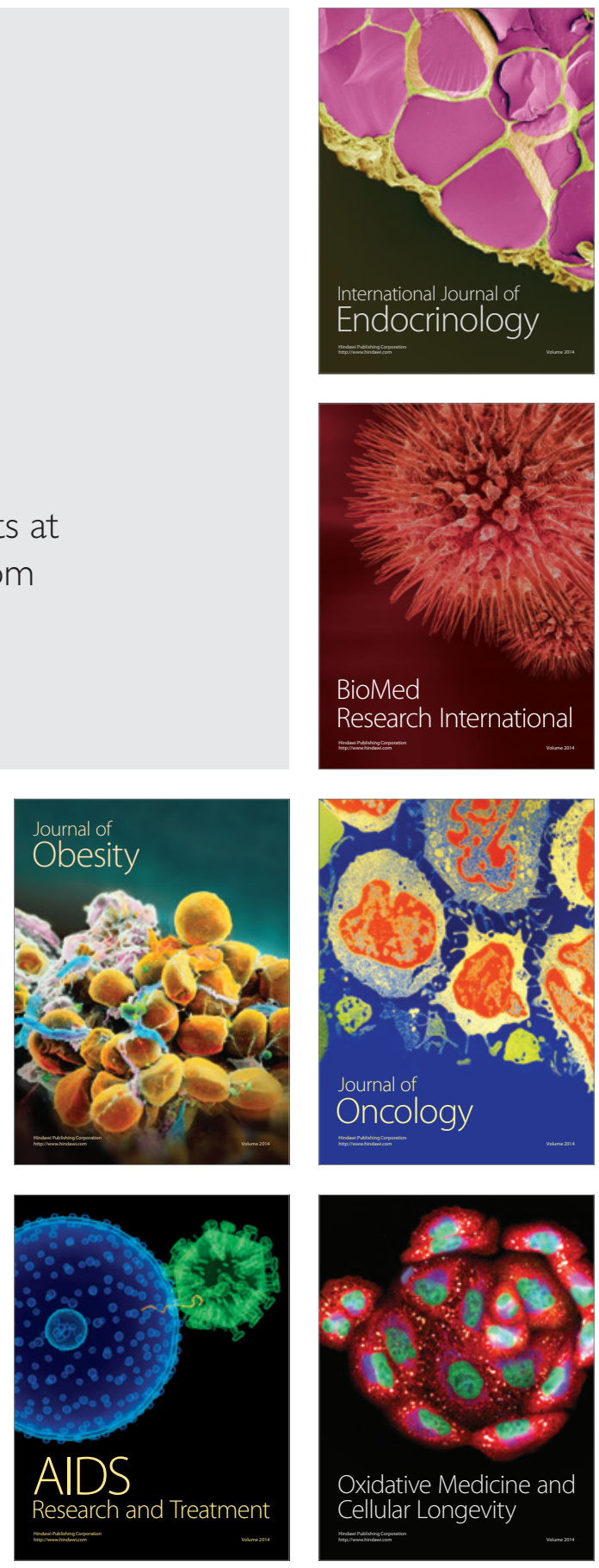